Dhaka Univ. J. Biol. Sci. 19(1): 21-26, 2010 (January)

\title{
OTHER SIDE OF THE ASHULIA WETLAND: A LIMNOLOGICAL PURVIEW
}

\author{
M. Azmal Hossain Bhuiyan, Moniruzzaman KhondkeR ${ }^{1}$ \\ AND Z. N. TAHMIDA BEGUM \\ Department of Botany, University of Dhaka, Dhaka-1000, Bangladesh
}

Key words: Wetland, Physical factors, Chemical factors, Limnology, Phytoplankton, Macrophytes

\begin{abstract}
Limnology of a temporary wetland Ashulia was found highly seasonal. Fluctuations of water depth, water temperature, Secchi depth, $\mathrm{pH}$, conductivity, total dissolved solids, dissolved oxygen and alkalinity were studied in three different stations for one year. Water depth showed a range of $1.5-4.2 \mathrm{~m}$ and Secchi disc transparency from $0.07-2.15 \mathrm{~m}$. Annual ranges in respect of $\mathrm{pH}$, conductivity, total dissolved solids (TDS), dissolved oxygen (DO) and alkalinity of water varied from 6.3 $7.2,92-1028 \mu \mathrm{S} / \mathrm{cm}, 43.4-491.0 \mathrm{mg} / \mathrm{l}, 4.3-28.9 \mathrm{mg} / \mathrm{l}$, and $0.71-6.45 \mathrm{meq} / \mathrm{l}$, respectively. The wetland showed a good to moderate water quality during rainy season because in this season visibility of water increased, TDS load, alkalinity and conductivity came down to their lowest. Dissolved oxygen content also showed an acceptable water quality value during rainy season.
\end{abstract}

\section{Introduction}

Wetlands in Bangladesh have great ecological, economic, commercial and socioeconomic values. They contain very rich components of biodiversity of national and regional significance. ${ }^{(1-2)}$ The total area of wetlands in Bangladesh is about 8 million ha of which nearly 4.3 million ha belongs to natural wetlands. ${ }^{(3-4)}$ Some of the important domains of natural wetlands are water transport, capture fisheries, biomass production, recreation and support for food chain. Of the natural wetlands, Islam $^{(5)}$ studied the hydrobiology of the Haor Hakaluki. Later limnological studies of wetland ecosystems of Bangladesh. (6-12) Most of those works were concentrated to deepwater rice fields, Beel ecosystems and marshlands situated in different parts of Bangladesh. There are some important wetlands surrounding Dhaka Metropolis. Limnology of Khilkhet Beel and some nearby ponds (c $15 \mathrm{~km}$ north of Dhaka Metropolis) was studied.(13) Another famous wetland near Dhaka Metropolis is Ashulia. It is a vast water body and takes a panoramic view during rainy season. Many a city dwellers visit this place year round. Open water capture fishery is also an important activity upon which livelihood of many inhabitants from the

${ }^{1}$ Corresponding author. 
surrounding areas depend. Considering the importance of this wetland the present limnological investigation was undertaken.

\section{Materials and Methods}

The study was carried out from September 2000 to August 2001 in the wetland Ashulia. It is situated in the north western part of Dhaka metropolis and is about 30 $\mathrm{km}$ away from the city centre. Via western fringe of the wetland Ashulia, river Turag flows (Fig. 1). At rainy season, overflow from Turag inundates the eastern part of the

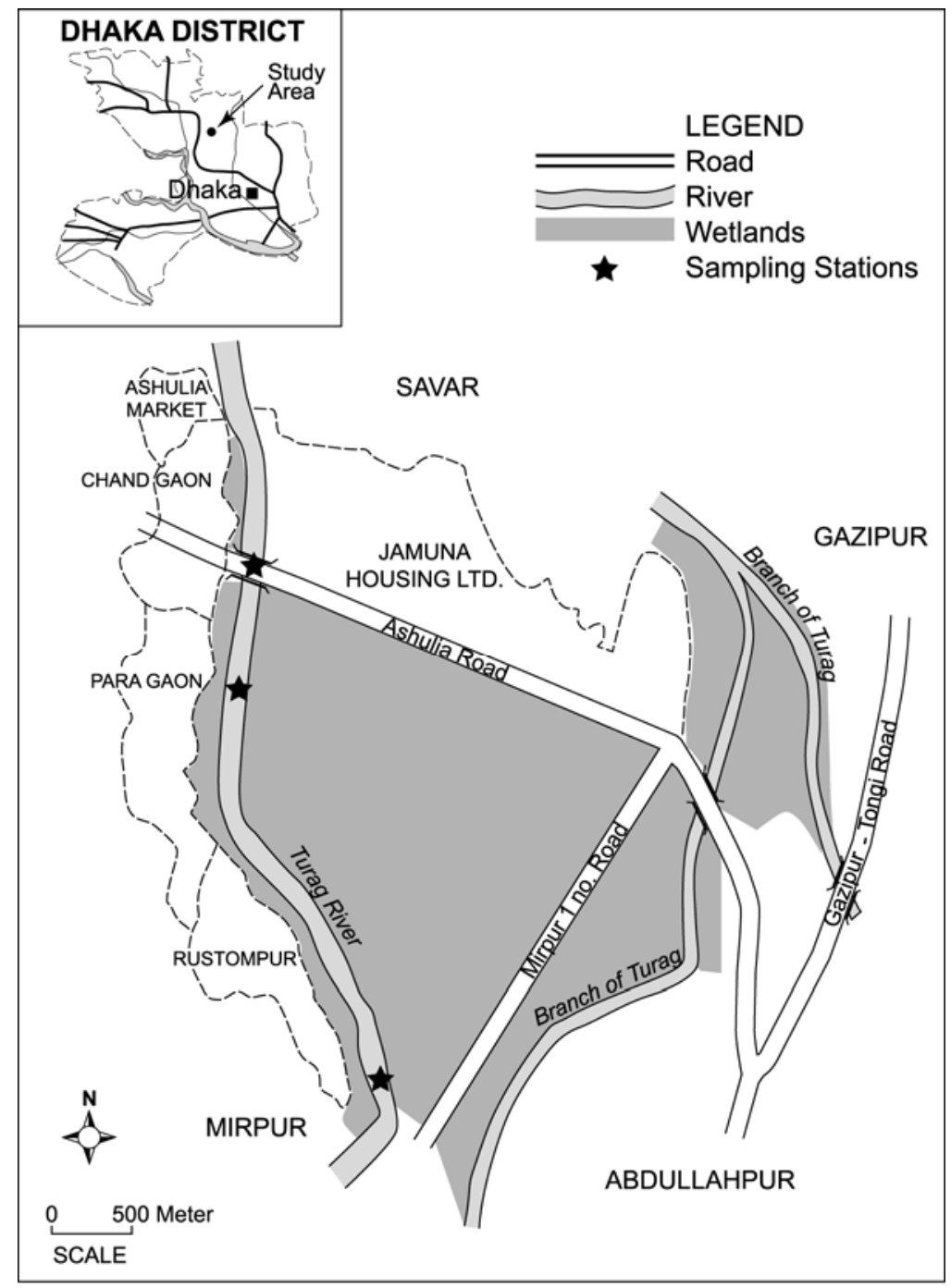

Fig. 1. Map of the sampling sites. 
wetland which dries out in dry season and converted into rice fields. Therefore, three study stations were set up along a $2 \mathrm{~km}$ stretch of the river Turag for carrying out the sampling year round (Fig. 1). The estimated area of the wetland is about 743 ha. Sampling was done fortnightly. At each station water temperature, water depth, Secchi depth and $\mathrm{pH}$ were measured in situ. Duplicate Pyrex glass bottles $(125 \mathrm{ml}$ capacity) were filled with sample water at each station and fixed by adding Winkler's reagent for the determination of dissolved oxygen (DO). One litre sample water from a depth of $20 \mathrm{~cm}$ below the surface was collected from each station for chemical analysis. The samples were brought to the laboratory and its alkalinity and conductivity were measured.(14-15) The data from all the three stations were transformed into mean values \pm sd and plotted.

\section{Results and Discussion}

Annual trend of the measured variables has been presented in Fig. 2A-D. A strongly seasonal relationship in the water depth of the wetland was exhibited. Highest water depth was recorded in September which started decreasing in the onset of November reaching its lowest value in February. Beginning from April water depth started rising and again reached its maxima in August (Fig. 2B). However extremely lowest Secchi depth was observed throughout the whole period ranging from October to July. Slight improvement in the Secchi depth was found in September and August (Fig. 2B). Beginning from October, the water temperature started falling reaching a lowest value in January then rose up again showing a highest value in May (Fig. 2A). Water $\mathrm{pH}$ ranged rather in an irregular mode having its peak in April and a minimum in July (Fig. 2A). Both the TDS and conductivity values related directly to each other showing a peak in April (Fig. 2C). During most of the study periods, concentration of dissolved oxygen remained in between 5 and 6 $\mathrm{mg} / \mathrm{l}$ except the months of March and April (Fig. 2D). Alkalinity was more or less uniform in most of the parts of the present study (Fig. 2D). The seasonal trends of the limnological variables were quite conspicuous. Monsoon is the season during which water depth and temperature showed a highest value (Table 1). Compared to other seasons the Secchi depth also improved $(0.59 \mathrm{~m})$. Among the other water quality parameters, $\mathrm{pH}$, conductivity, TDS, and alkalinity dropped in monsoon (Table 1). Dissolved oxygen of water was lowest in autumn and highest in summer. During summer, seasonal mean values for $\mathrm{pH}$, dissolved oxygen, alkalinity, TDS and conductivity were high (Table 1).

Ashulia is a temporary wetland and its limnology is highly seasonal. After peaking the water depth in monsoon actually a lot of dilutions in its water occur as a result Secchi depth increases but $\mathrm{pH}, \mathrm{DO}$, conductivity and TDS content drop (Table 1). In monsoon, conductivity of water decreases nearly seven times from its previous 

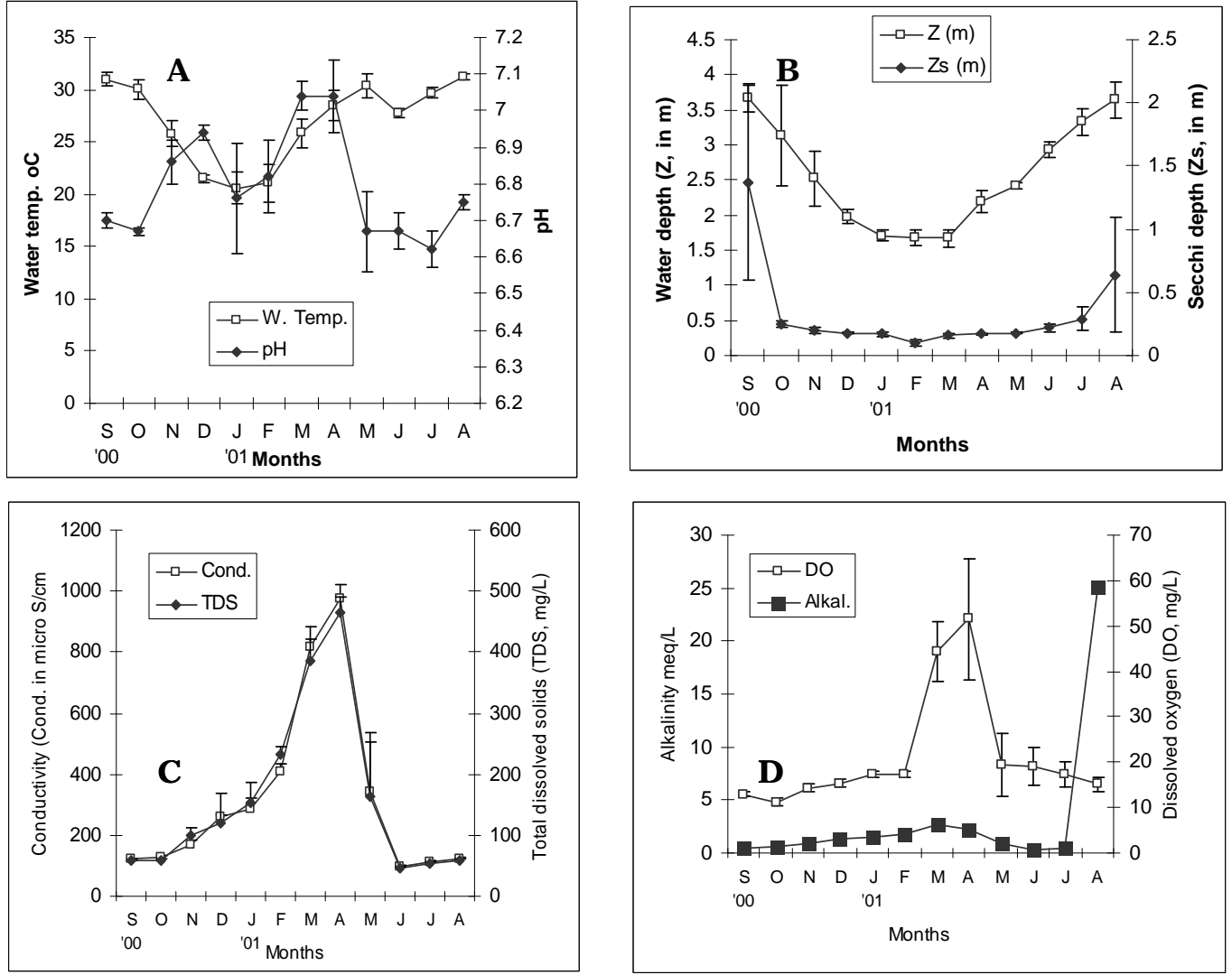

Fig. 2A-D. Annual fluctuations of A, water temperature and $\mathrm{pH}$; B, water depth and Secchi depth; C, conductivity and total dissolved solids; D, dissolved oxygen and alkalinity of water.

Table 1. Mean ( $\pm s d)$ values of different limnological parameters of wetland Ashulia over the four major seasons of Bangladesh.

\begin{tabular}{lllll}
\hline Parameters & Winter & Summer & Monsoon & Autumn \\
\hline Water temp. $\left({ }^{\circ} \mathrm{C}\right)$ & $21.6 \pm 1.9$ & $28.2 \pm 2.3$ & $30.0 \pm 1.4$ & $28.1 \pm 1.7$ \\
Water depth $(\mathrm{m})$ & $1.89 \pm 0.33$ & $2.09 \pm 0.34$ & $3.42 \pm 0.40$ & $2.56 \pm 0.42$ \\
Secchi depth $(\mathrm{m})$ & $0.16 \pm 0.04$ & $0.17 \pm 0.16$ & $0.59 \pm 0.61$ & $0.22 \pm 0.03$ \\
pH & $6.85 \pm 0.12$ & $6.92 \pm 0.19$ & $6.62 \pm 0.13$ & $6.74 \pm 0.06$ \\
DO $(\mathrm{mg} / \mathrm{l})$ & $7.06 \pm 0.53$ & $16.48 \pm 7.17$ & $6.64 \pm 1.60$ & $5.49 \pm 0.35$ \\
Alkal. $(\mathrm{meq} / \mathrm{l})$ & $3.43 \pm 0.63$ & $4.54 \pm 1.82$ & $1.04 \pm 0.16$ & $1.59 \pm 0.28$ \\
Cond. $(\mu \mathrm{S} / \mathrm{cm})$ & $298.1 \pm 103.3$ & $710.3 \pm 294.0$ & $115.7 \pm 10.8$ & $146.0 \pm 12.7$ \\
TDS $(\mathrm{mg} / \mathrm{l})$ & $165.9 \pm 47.9$ & $337.4 \pm 140.0$ & $54.3 \pm 5.4$ & $73.3 \pm 13.3$ \\
\hline
\end{tabular}

season summer (Table 1). A slight increase in conductivity occurred in autumn. Begum et al. ${ }^{(9)}$ studied the water quality of deepwater rice fields of Sonargaon and 
found lower values $(30-58 \mu \mathrm{S} / \mathrm{cm})$. However, in some temporary marshlands near Rajendrapur, Dhaka water conductivity in autumn varied from 154.5 - 175.0 $\mu \mathrm{S} / \mathrm{cm} .{ }^{(12)}$ In autumn mean $\mathrm{pH}$, conductivity, DO and alkalinity for this marshland were recorded as 6.7 and $163.7 \mu \mathrm{S} / \mathrm{cm}, 4.69 \mathrm{mg} / \mathrm{l}$ and $1.54 \mathrm{meq} / \mathrm{l}$, respectively. ${ }^{(12)}$ The values are quite comparable with those obtained in Ashulia in autumn (Table 1). Annual mean $\mathrm{pH}$ and conductivity of Khilkhet Beel were reported as 7.06 and 121.7 $\mu \mathrm{S} / \mathrm{cm}$, respectively. ${ }^{(13)}$ Pulling the annual mean values of these two parameters for wetland Ashulia a lower $\mathrm{pH}(6.78)$ and a high conductivity $(317.5 \mu \mathrm{S} / \mathrm{cm})$ were obtained. In case of wetland Ashulia river Turag actually receives pollutants from Tongi industrial area and all these might be the reason for high conductivity values. The conductivity showed a seasonal maximum $(710.3 \mu \mathrm{S} / \mathrm{cm})$ in summer when the wetland actually shrinks in its size only leaving the flow of the river Turag. Ashulia is not a deepwater rice field rather its vast open water act as an excellent ground for capture fisheries and tourist activities to a limited scale. So far its limnology is concerned, the wetland shows a good to moderate water quality during rainy season because in this season visibility of water increases. TDS load, alkalinity and conductivity came down to their lowest or minimum and dissolved oxygen content also showed an acceptable water quality value.

\section{References}

1. Anonymous 1992. Action Programme for the Conservation of Wetlands in South and West Asia. AWB, Kuala Lampur and IWRB, Slimbridge, pp. 1-32.

2. Nishat A 1993. Freshwater wetlands in Bangladesh: status and issues. In: Freshwater Wetlands in Bangladesh: Issues and approaches for management (Nishat, A., Hussain, Z., Roy, M.K. and Karim, A. eds.) IUCN Gland, Switzerland. pp. 9-21.

3. Akando AW 1989. Bangladesh. In: DA Scott (ed.). A directory of Asian Wetland. IUCN. Gland Switzerland and Cambridge. pp. 541-581.

4. De Silva SS 1995. The Asian inland fishery with special reference to reservoir fisheries: A reappraisal. In: Tropical Limnology Vol. I (Timotius, K.H. and Göltenboth, F. eds) pp. 45-55. Satya Wacana Christian University, Salatiga, Indonesia.

5. Islam AKM Nurul and N Paul 1978. Hydrobiological study of the Haor Hakaluki in Sylhet. J. Asiatic Soc. Bangladesh (Sci.) 4(1): 83-91.

6. Catling D, MR Martinez and Z Islam 1981. Survey of algae associatied with deepwater rice in Bangladesh. Crypt. Algol. II, 2: 109-121.

7. Whitton BA, A Aziz, P Francis, JA Rother, JW Simon and ZN Tahmida 1988. Ecology of deepwater rice-fields in Bangladesh 1 . Physical and chemical environment. Hydrobiologica 109: 3-67.

8. Aziz A and BA Whitton 1988. Influence of light flux on nitrogenase activity of the deepwater rice-field cyanobacterium (blue-green alga) Gloeotrichia pisum in field and laboratory. Microbios 53: 7-19. 
9. Begum ZN, R Mandal and AR Paul 1988. Succession of algal flora in deep water rice field of Sonargaon, Bangladesh. Phykos 27: 15-24.

10. Aziz A and Ahmed QA 1992. Occurrence and biomass of algae epiphytic on deepwater rice plants near Sonargaon, Bangladesh. Arch. Hydrobiol. 125: 479-486.

11. Talukder AKMH, M Khondker and KK Anam 1994. Water quality: in the environmental perspective of north western region of Bangladesh. Bangladesh J. Sci. Res. 12(1): 49-54.

12. Abdullah ANM, A Khanam, AKM Nazrul-Islam, T Jamali and A Ahmed 2003. Ecology and species composition of a temporary marshland. Geobios 30: 9-16.

13. Islam AKMN, M Khondker, A Begum and N Akter 1992. Hydrobiological studies in two habitats at Dhaka. J. Asiat. Soc. Bangladesh, Sci. 18(1): 47-52.

14. Mackereth FJH, J Heron and JF Talling 1978. Water analysis: some revised methods for limnologists. Freshwater Biol. Assoc. Pub. No. 36, pp. 120.

15. Wetzel RG and GE Likens 1979. Limnological analysis. W.B. Saunders Co., Philadelphia, pp. 357.

(Manuscript received on 2 February, 2009; revised on 30 March, 2009) 